\title{
Editorial
}

\section{Witness in America}

\author{
M.N.G. Dukes \\ Groningen University, Groningen, Netherlands
}

The closer the countries of the world grow together, the more sharply do some national characteristics seem to be thrown into profile. Medicine has become internationalized more rapidly than has law; but on the medico-legal borderland we cling oh so firmly to, our particular concepts as to the standards we proclaim and the way in which we seek to maintain them, the mere European who finds himself called into an American case may find himself entangled in situations for which he had not bargained.

My own incidental ventures as an expert witness into the American courtroom relate to an area in which one might expect a reasonable sameness across the world, namely adverse reactions to drugs, and the proceedings to which they unhappily give rise [1]. Medicines, patterns of toxicity and drug corporations are, after all, much the same everywhere. Yet I have found myself variously delighted, disorientated or disconcerted; occasionally, I have flown home shaking my head.

Like many other Europeans, I was taught to believe that litigation in matters medical was a singularly American disorder, only mildly contagious but possibly incurable once it had taken root. I have retained some distaste for it, and particularly for its disruptive effects on the practice of honest medicine, but also a healthy respect for the occasions on which it does do a degree of good. Such conclusions one might naturally draw even at a distance; but to enter the American courtroom confronts one, despite half a lifetime of exposure via Hollywood, with a novel sense of how the system at its best and worst actually functions. At its best, it is very, very good. However vehement voices in the courtroom may become, the judge excludes an aura of composure which maintains one's trust in the process. The judges before whom I have appeared have coupled an unbelievable erudition with a feeling for practical good sense, in matters ranging from advertising mores to libido, which I would not expect so consistently from the courts with which I am more familiar. "Ah, yes, Mr. Morris", murmurs the bench at the critical instant and with just a shade too much emphasis on the affirmative, and an attorney's well-rehearsed doctrine as to why acetophenitidine must have rendered his client bald promptly collapses like the bubble of irrelevances which it is, leaving him fluttering uncertainly before the jury. 
Juries, a revelation to the European more accustomed to justice exclusive from the judge's seat, I am coming to adore. It is admittedly disconcerting to find one's performance before them being rehearsed on video, with due censorship of my dress, my haircut and any mode of speech which might impinge on their religious persuasions; but it proves wholesome to have to put the complexities of enzyme induction into clear, common-sense language. Litigation lawyers? I am less sure what to think of them; I have been privileged to pick my partners, but I have also encountered some extremely worthy opponents with whom one seemed to share a desire to get at the truth; the exceptions have variously terrorised my fellow witnesses into withdrawal, held me up to cheap ridicule at deposition ("Do you actually mean to tell me, Professor, that you are not qualified to practice polysomnography in this State?") and entered into some curious attempts to blacken my moral reputation in the eyes of the jury.

When my medical colleagues come to give testimony, they sometimes seem a conundrum apart. The old adage that doctors differ is nowhere more sharply profiled than before an American court. Litigation lawyers seem to have no difficulty in finding practising physicians ready to subscribe on oath to the most astonishing postulates, and others prepared to contradict them in an equally solemn manner. In my own limited view their contribution to the work of the courts has proved abortive for that very reason. They are listened to with forbearance, and then despatched so that the court can summon the statisticians, the pathologists and such academics as myself who are at least supposed to have a more objective view of matters. That is troubling; if truth is to be distilled from medical evidence it is surely truth which is more closely related to the consulting room than to the blackboard and the laboratory. The truly sorry characters in court, I fear, are the people whom I can only characterize as professional expert witnesses, borrowing the term from the world's oldest calling; having by mere chance experienced such a hack at work in two different cases - in each merely appending a signature and a presentation for three thousand dollars a day to a document written by his principals. I wonder, what is the right name for that? One hesitates to call it perjury, but it smells a little rancid.

Where procedures are concerned I have nothing but admiration for the way Americans do their preparatory work, provided they recycle the staggering quantities of paper involved. The manner in which the discovery process enables one to ransack the filing cabinets and cellars of the opposing party in order to dig down (sometimes almost literally) to the truth, is a revelation; so too is the openness provided by the Freedom of Information Act, bringing a great deal out of the shadows cast by authority.

In theory I might have been subpoenaed to appear in matters not to my liking; in practice, I have been privileged for five years to limit my involvement to causes and parties which I believed deserved my support. That has sometimes involved dancing with mastodons; when one has linked arms with Monsanto [2] or SmithKline Beecham [3] one has to dance fairly astutely to retain one's freedom of movement. It has also involved facing the lions; I do not know that either Upjohn [4] or Parke Davis [5] have much residual affection for me, but some other lions 
appear to have licked their wounds and become wiser from the encounter; sometimes, so have I. Too much of what I have seen has related to the suppression by pharmaceutical companies, in one country or another, of information on adverse drug reactions; that does not undermine the basic principle that the industry can and often does behave honestly in such matters, but it reminds me that there are some glaring exceptions to the rule; it is painful but good that those exceptions be hammered out in court, for that underlines the importance to society of the rules which have been broken.

I had not expected to become a champion on my own side of the Atlantic for the American way of taking medical and pharmaceutical disputes to court. To an extent, I am becoming one now, for sometimes it delivers justice and does so in a commendably open manner. It is good that in Europe, with our disciplinary tribunals, compensation schemes and insurance company assessors, we handle medical disputes as quietly as we can, but there are some matters which are better not dealt with so cosily. A case of criminally careless practice or disreputable drug-making may deserve to be spelled out in public so that the lesson is driven home. Some medical issues will be settled more firmly and finally by confrontation in a court than by polite debates at a conference. Are water soluble contrast media safely used? Does triazolam drive people mad? Are anti-epileptics teratogenic? Should one warn about what antirheumatics do to the liver? When should fault be placed at the door of the FDA rather than with an honest drug manufacturer? Litigation has thrown into focus some horrors hidden too long, but it has equally provided some well-deserved acquittals; I could never find evidence that either Depo-Provera ${ }^{\circledR}$ or Bendectin ${ }^{\circledR} /$ Debendox ${ }^{\circledR}$ were the evil things which they were made out to be, and courts have generally and generously acquitted them.

Clearly, the system has its defects; what one gains on the swings, as the English say, one may lose on the roundabouts. Punitive damages, imposed by a court which has no criminal jurisdiction, sometimes seem to turn justice into vengeance. Nor can I feel happy about the sort of judicial manipulation which merely seems designed to impose liability on any party sufficiently well-heeled to pay compensation; it can leave a grossly undeserved stain on the reputation of a decent doctor or an equally decent vaccine manufacturer. Such shadows apart, American drug litigation remains a system which can deliver justice - sometimes approximative, late and inordinately costly, but justice all the same - in situations where something has gone wrong with the processes which are supposed to protect the public interest and where there is no other remedial process within reach.

\section{References}

1 Dukes MNG, Swartz B. Responsibility for Drug-Induced Injury. New York, Amsterdam and Oxford: Elsevier Science Publishers, 1988.

2 Unpublished case heard in arbitration, and relating to the concealment of adverse reactions by an industrial party.

3 Albert Rolland SA v. SmithKline Beecham Corp. United States District Court for the Eastern District 
of Pennsylvania: opinion of May 22nd 1990, per vanArtsdalen S.J. Case relating the alleged concealment of adverse reactions to ticrynafen.

4 Greenberg $v$. Upjohn. Unpublished Utah case relating to alleged injury by triazolam; settled out of court. For an account see Newsweek, August 19th 1991.

5 Unpublished case relating to alleged teratogenic effects of an anti-epileptic drug. 